\title{
HAK ASASI MANUSIA DI INDONESIA DI TINJAU DARI BERBAGAI ASPEK KEHIDUPAN
}

\author{
Dewi Lestari, S.H. ${ }^{1}$
}

Abstrak

The author here does elaboration concerning human rights concourse in wide and launched many examples on violations since long time ago. The explanation concerning human rights in this article talking the trend in post world war 2 that also was influenced into newly Indonesia state in 1945. Embark from the contemporary and trend then many law and policy have been promulgated to giving assurance on human rights protection in most countries over the world. But then aroused inconsistency through human rights enforcement and here the author introduce some principal problems on the many cases violation and specificly in what have happened over children and women until recent times. Here the author suggested to new paradigm to oversee children and women as victim of human rights violence in inclusive and comperehensive approaches.

Kata kunci: hak asasi manusia, wanita dan anak-anak, kajian, aspek kehidupan

Para founding fathers mencita-citakan Indonesia sebagai negara yang berdasarkan hukum (rechsstaat) dan bukan negara yang berdasarkan kekuasaan (machsstaat). Sebagai negara hukum, Indonesia harus mengakui dan menjunjung tinggi hak asasi manusia. Hak asasi manusia merupakan hak yang hakiki yang telah dimiliki seseorang sejak lahir. Hak ini inherent dalam diri setiap orang dan tidak dapat diambil, dicabut, dirampas, atau dialihkan kepada orang lain untuk dan oleh siapapun.

Dasar-dasar hak asasi manusia tertuang di dalam berbagai instrumen internasional di antaranya adalah Universal Nations of Human Rights, International Covenant on Civil and Political Rights, International Covenant on Economic, Social and Cultural Rights. Selain itu hak asasi manusia tercantum pula dalam instrumen nasional yaitu di dalam Undang-Undang Dasar 1945 Republik Indonesia (UUD 1945). Dalam UUD 1945, hak asasi manusia tersebut tercantum di dalam berbagai pasal, diantaranya adalah Pasal 27 ayat 1 tentang persamaan kedudukan di hadapan hukum, Pasal 28

\footnotetext{
${ }^{1}$ Penulis adalah Associate pada Kantor Konsultan Hukum IKS \& Partners Attorneys at Law dan mahasiswa program pascasarjana di Universitas Gadjah Mada kelas Jakarta.
} 
tentang kebebasan berserikat dan berkumpul, mengeluarkan pikiran dengan lisan dan tulisan, Pasal 29 ayat 2 tentang kebebasan beragama dan beribadat sesuai dengan kepercayaan, Pasal 30 ayat 1 tentang hak dalam usaha pertahanan dan pembelaan negara, Pasal 31 ayat 1 tentang hak mendapatkan pendidikan, dan Pasal 34 ayat 1 tentang pemeliharaan fakir miskin dan anakanak terlantar oleh negara.

Banyak bidang dan berbagai jenis hak asasi manusia yang diakui, salah satunya dengan disahkannya Undang-Undang No. 39 Tahun 1999 tentang Hak Asasi Manusia. Namun dalam praktiknya, hak asasi manusia yang diakui secara umum adalah hak untuk hidup, hak untuk memperoleh pendidikan, hak untuk hidup bersama-sama seperti orang lain, hak untuk mendapatkan perlakuan yang sama, hak untuk mendapatkan pekerjaan, hak memperoleh bantuan hukum, dan sebagainya. Bahkan hampir di setiap aspek kehidupan setiap orang memiliki hak asasi. ${ }^{2}$

Pada zaman perang dunia ke II, Presiden Franklin D. Roosevelt mengidentifikasikan empat kebebasan yang diupayakan untuk dipertahankan di dalam perang tersebut, yaitu kebebasan berbicara dan berekspresi, kebebasan beragama, kebebasan dari hidup berkekurangan, dan kebebasan dari ketakutan akan perang. ${ }^{3}$

\section{Pelanggaran Hak Asasi Manusia Terhadap Anak}

Jenis pelanggaran hak asasi manusia yang paling sering terjadi adalah kekerasan terhadap manusia. Karena kekerasan adalah suatu tindakan yang paling mudah dilakukan oleh pihak yang kuat untuk menindas pihak yang lemah. Tindakan pelanggaran hak asasi manusia ini selalu terjadi dengan berbagai bentuk dan jenis kekerasan. Yang paling sering menjadi korban adalah perempuan dan anak-anak. Pada dasarnya kekerasan merupakan akar dari pelanggaran asasi manusia. Oleh karena itu, kekerasan semacam ini terus terjadi dan berlarut-larut tanpa ada kesadaran baik dari korban maupun pelaku untuk menanggulanginya. kekerasan memang harus segera diakhiri dan kekerasan merupakan pelanggaran hak asasi manusia yang seringkali terjadi dan menimbulkan rasa tidak aman dan was-was kepada korbannya.

${ }^{2}$ Untuk naskah "Declaration by United Nations" tertanggal 1 Januari 1942. lihat H.F. van Panhuys dkk., ed., International Organization and Integration (The Hague: Martinus Nijhoff, 1981), Vol. 1A.

${ }^{3}$ Lihat Douglas Lurton, Roosevelt's Foreign Policy, 1933 1941: Franklin D. Roosevelt's Unedited Speeches, (Toronto: Longmans, Green, 1942), 324. 
Dimulai dengan penghargaan hak asasi manusia yang sederhana barulah hak asasi manusia lainnya dapat juga dibentuk.

Dapat kita saksikan di media massa dan media elektronik yang menyajikan beragam tindak kekerasan yang berujung pada tindakan kriminal. Dari salah satu sumber didapatkan bahwa, anak-anak merupakan kelompok yang paling rentan menjadi korban kekerasan. Laporan Komisi Perlindungan Anak menunjukkan tindak kekerasan terhadap anak dari tahun ke tahun terus meningkat. Pada tahun 2004 tercatat 547 kasus, tahun 2005 tercatat 736 kasus, dan pada Januari-Juni 2006 tercatat 426 kasus. Jika hal ini dibiarkan berlarut-larut maka tak pelak lagi akan menjadi akar perusak moral dan masa depan bangsa Indonesia".

Anak-anak yang mengalami kekerasan akan menjadi trauma dan terus dibayangi oleh rasa ketakutan dan tidak aman. Padahal untuk menjadi generasi muda yang diharapkan dapat meneruskan cita-cita bangsa, anakanak harus mendapatkan perlindungan, pendidikan yang baik, dan memiliki semangat yang tinggi. Namun bagaimana mungkin rasa aman, pendidikan yang baik, dan semangat yang tinggi tersebut dapat tumbuh dan berkembang sebagaimana yang diharapkan, jika hidup anak-anak tersebut dipenuhi dengan kekerasan, rasa takut, dan secara psikologis terus dibayangi dengan perasaan was-was.

Kasus kekerasan di Indonesia tidak mencuat karena tidak ada laporan resmi dari korban kepada aparat penegak hukum atau kepada komisi perlindungan anak. Hal ini terjadi karena lingkungan budaya yang sudah mengakar. Masyarakat tradisional tidak mengakui insiden semacam itu sebagai pelanggaran hak asasi manusia. Buruknya penegakan hukum yang kurang memadai di bidang tersebut dan dan merajalelanya korupsi di kalangan penegak hukum, juga membuat kasus-kasus kekerasan semacam luput dari penyelidikan. Akibatnya pelaku tindak kekerasan terhadap anak pun bebas dari jeratan hukum.

Seperti halnya anak-anak di belahan dunia lain, anak-anak di Indonesia pun mengalami kekerasan dalam rumah tangga, di jalanan, di sekolah, dan di antara teman sebaya mereka. Tapi banyak kasus kekerasan semacam ini tidak terungkap. Atau, hal ini tidak dianggap sebagai kasus kekerasan karena kedua pihak tidak menganggapnya sebagai masalah. Seringkali kekerasan terhadap anak dianggap hal yang lumrah karena secara sosial dipandang sebagai cara pendisiplinan anak. Bahkan di banyak masyarakat, norma sosial dan budaya tidak melindungi atau menghormati anak-anak.

Ada beberapa fakta yang cukup memprihatinkan, dimana fakta ini merupakan titik awal rendahnya penghargaan terhadap hak asasi manusia. Diperkirakan sekitar 60 persen anak balita Indonesia tidak memiliki akte kelahiran. Ini artinya, anak-anak tersebut akan kesulitan untuk memperoleh 
hak-hak yang kiranya layak untuk didapat mereka sebagai warga negara Indonesia. Sebagai contoh adalah proses pendidikan yang persyaratannya harus memiliki dokumen-dokumen hukum yang jelas salah satunya adalah akta kelahiran. Contoh lainnya adalah seorang warga negara yang ingin memperoleh perlindungan hukum diwajibkan untuk memiliki surat identitas yang jelas seperti kartu tanda penduduk. Apabila dari balita saja hak-hak mereka telah diabaikan, dapat kita bayangkan kehidupan yang harus mereka jalankan nantinya.

Fakta lain menunjukkan bahwa lebih dari 3 juta anak terlibat dalam pekerjaan yang berbahaya. Jelas fakta ini menujukkan adanya pelanggaran hak asasi manusia. Anak-anak dijadikan komoditas bisnis baik oleh orang tuanya atau pihak-pihak yang memiliki kepentingan di dalamnya. Terlepas dari aspek ekonomi, fakta ini menunjukkan bahwa telah terjadi pencabutan hak asasi anak-anak untuk memperoleh pendidikan, karena waktu belajar mereka telah dirampas untuk menjadi pekerja.

Bahkan, fakta lain yang lebih mengerikan adalah sekitar sepertiga pekerja seks komersil berumur kurang dari 18 tahun. Sementara 40.00070.000 anak lainnya telah menjadi korban eksploitasi seksual. Ditambah lagi sekitar 100.000 wanita dan anak-anak diperdagangkan setiap tahunnya. Belum lagi 5.000 anak yang ditahan atau dipenjara dimana 84 persen di antaranya ditempatkan di penjara dewasa. Masalah lain yang tak kalah memprihatinkan adalah pelecehan terhadap anak terutama anak-anak dan wanita yang tinggal di daerah konflik atau daerah bekas bencana. Lebih dari 2.000 anak tidak mempunyai orang tua. Angka-angka dan persentase yang dijabarkan tersebut bukanlah angka-angka dan persentase yang stagnan, melainkan angka-angka dan persentase yang terus meningkat pesat.

\section{Penanggulangan Pelanggaran Hak Asasi Manusia Anak dan Perempuan Ditinjau dari Segi Yuridis}

Salah satu cara mengurangi angka kekerasan adalah dengan mengikis akar kekerasan dan pelanggaran hak asasi manusia sejak usia dini. Artinya pemahaman yang benar tentang bahaya kekerasan kepada anak-anak harus benar-benar ditanamkan kepada semua lapisan masyarakat. Bahkan seharusnya pengetahuan tentang hak asasi manusia kepada anak-anak ditanamkan sejak usia dini. Misalnya di usia Sekolah Dasar anak-anak diberi pengenalan tentang nilai-nilai hak asasi manusia dan memberikan pengetahuan tentang haknya mengenai memperoleh rasa aman dan bebas dari segala macam bentuk kekerasan. 
Undang-Undang Nomor 23 Tahun 2002 tentang Perlindungan Anak diadakan dengan tujuan menjamin terpenuhinya hak-hak anak agar dapat hidup, tumbuh, berkembang, dan berpartisipasi optimal sesuai harkat dan martabat kemanusiaan, mendapat perlindungan dari kekerasan dan diskriminasi. Namun sudah disahkan selama empat tahun, pelaksanaan di lapangan belum berjalan seperti yang diharapkan. Masing-masing pihak yang terlibat dalam pelaksanaan undang-undang itu menyampaikan sederet persoalan yang secara nyata mereka hadapi sehari-hari di lapangan dalam pelaksanaan undang-undang tersebut. Persoalan mendasar di sini adalah meskipun Undang-Undang Perlindungan Anak sudah berlaku selama empat tahun, tetapi kekerasan terhadap anak tidak menyurut. Kekerasan terhadap anak perempuan, terutama kekerasan seksual, terus menghiasi media massa kita. Bahkan yang terungkap hanya sepersekian dari kejadian yang terjadi di lapangan, fenomena ini sering disebut sebagai fenomena gunung es. Hanya peristiwa yang terekspos oleh media massa saja yang menjadi perhatian masyarakat, sedangkan peristiwa- peristiwa lainnya tenggelam begitu saja.

Ada beberapa hak asasi manusia yang melekat pada setiap diri anak di Indonesia sebagaimana diatur dalam Undang-Undang Perlindungan Anak. Kebebasan untuk beribadah sesuai agamanya, perlindungan jaminan kesehatan, dan hak mendapat pendidikan adalah sebagian isi dari UndangUndang Perlindungan Anak tersebut. Sementara perlindungan yang sifatnya khusus diberikan antara lain untuk anak dalam situasi darurat, anak yang berhadapan dengan hukum, anak dari kelompok minoritas dan terisolasi, anak yang tereksploitasi secara ekonomi-seksual, anak yang diperdagangkan, anak korban penyalahgunaan narkotika, anak korban kekerasan fisik-mental, anak cacat, serta anak korban perlakuan salah dan penelantaran, yang diatur dalam Pasal 59.

Salah satu alasan mengapa Undang-Undang Perlindungan Anak harus dilaksanakan adalah karena undang-undang ini memberikan perlindungan yang lebih baik dibandingkan dengan KUHP. Misalnya, seperti disebutkan LBH APIK, ada sanksi cukup tinggi berupa hukuman pidana penjara maksimal 15 tahun dan minimal 3 tahun dengan denda maksimal Rp 300 juta dan minimal 60 juta untuk tindakan yang berhubungan dengan perkosaan dan percabulan terhadap anak yang diatur di dalam KUHP.

Ketidakpedulian pemerintah melaksanakan amanah undang-undang itu berdampak pula di dalam kebijakan anggaran negara. Budgeting terhadap pelaksanaan amanah Undang-Undang Perlindungan Anak sangat kecil bahkan bisa dibilang tidak mampu memberikan kontribusi apapun. Menghadapi kondisi tersebut, tidak bisa tidak, masyarakat madani harus salaing bahu membahu menganggulangi permasalahan sosial dan hukum ini 
dengan membangun jaringan dan bekerja di semua lini, dari tingkat kebijakan hingga ke akar pokok-pokok permasalahan.

\section{PBB dan Hak Asasi Manusia}

Pada awalnya ide dan konsep tentang hak asasi manusia yang dikenal sekarang berawal dari Perang Dunia II yang terjadi pada tahun 1939-1945. Dalam kurun waktu tersebut terlihat tidak adanya kepedulian terhadap kehidupan dan kebebasan manusia. Pembunuhan dan kerusakan dahsyat yang ditimbulkan Perang Dunia II menggugah suatu kebulatan tekad untuk melakukan sesuatu guna mencegah perang, untuk membangun sebuah organisasi internasional yang sanggup meredakan krisis internasional serta menyediakan suatu forum untuk diskusi dan mediasi. Organisasi ini adalah Perserikatan Bangsa-Bangsa (PBB), yang telah memainkan peran utama dalam pengembangan pandangan kontemporer tentang hak asasi manusia.

Para pendiri PBB yakin bahwa pengurangan kemungkinan perang mensyaratkan adanya pencegahan atas pelanggaran besar-besaran terhadap hak-hak manusia. Lantaran keyakinan ini, konsepsi-konsepsi PBB yang paling awal pun bahkan sudah memasukkan peranan pengembangan hak asasi manusia dan kebebasan. Naskah awal Piagam PBB (1942 dan 1943) memuat ketentuan tentang hak asasi manusia yang harus dianut oleh negara manapun yang bergabung di dalam organisasi tersebut, namun sejumlah kesulitan muncul berkenaan dengan pemberlakuan ketentuan tersebut. Lantaran mencemaskan prospek kedaulatan sebuah negara --dalam pandangan subyektif pemimpin yang otoriter dari suatu negara--, kemudian banyak negara bersedia hanya untuk "mengembangkan" hak asasi manusia tersebut namun tidak bersedia untuk "melindungi" hak tersebut. ${ }^{4}$

Akhirnya diputuskan untuk memasukkan sedikit saja acuan tentang hak asasi manusia di dalam Piagam PBB (UN Charter), di samping menugaskan Komisi Hak Asasi Manusia (Commission on Human Rights) -komisi yang dibentuk PBB berdasarkan sebuah ketetapan di dalam piagam

${ }^{4}$ Untuk sebuah tinjauan sejarah tentang Universal Declaration of Human Rights dan sebuah garis besar tentang isu-isu pokok yang diperdebatkan sebelum pemberlakuannya. lihat Louis B. Sohn. "A Short History of the United Nations Documents on Human Rights", di dalam Commission to Study the Organization of Peace, "The United Nations and Human Rights: Eighteenth Report of the Commission", (Dobbs Fery. New York: Transnational Publishers, 1968), 43-56; dicetak ulang di dalam Louis B. Sohn dan Thomas Buergenthal, ed.. "International Protection of Human Rights", (Indianapolis: Bobbs Merrill, 1973), 505. Simak juga John P. Humphrey, "Human Rights and the United Nations: A Great Adventure". (Dobbs Ferry, New York Transnational Publishers, 1984). 
tersebut -- untuk menulis sebuah pernyataan internasional tentang hak asasi manusia. Piagam itu sendiri menegaskan kembali "keyakinan akan hak asasi manusia yang mendasar, akan martabat dan harkat manusia, akan persamaan hak antara laki-laki dan perempuan serta antara negara besar dan negara kecil." Para penandatangannya mengikrarkan diri untuk "melakukan aksi bersama dan terpisah dalam kerja sama dengan Organisasi ini "untuk memperjuangkan" penghargaan universal bagi, dan kepatuhan terhadap, hak asasi manusia serta kebebasan-kebebasan mendasar untuk seluruh manusia, tanpa membedakan ras, jenis kelamin, bahasa atau agama." ${ }^{5}$

"Deklarasi Perserikatan Bangsa-Bangsa" (Declaration by United Nations) yang terbit pada 1 Januari 1942, menyatakan bahwa kemenangan adalah "penting untuk menjaga kehidupan, kebebasan, independensi dan kebebasan beragama, serta untuk mempertahankan hak asasi manusia dan keadilan." Dapat dilihat di sini, bahwa hak asasi manusia merupakan salah satu elemen dari tujuan deklarasi ini.

Dalam Universal Nations of Human Rights yang dideklarasikan pada 10 Desember 1948 memberikan pertimbangan bahwa pengakuan atas martabat alamiah dan hak-hak yang sama dan mutlak dari semua anggota keluarga manusia adalah dasar kemerdekaan, keadilan, dan perdamaian di dunia. Mengabaikan dan memandang rendah hak-hak asasi manusia telah mengakibatkan perbuatan-perbuatan tidak manusiawi yang menimbulkan rasa kemarahan hati nurani umat manusia, dan terbentuknya suatu dunia tempat manusia akan mengecap kenikmatan kebebasan berbicara dan beragama serta kebebasan dari ketakutan dan kekurangan telah dinyatakan sebagai cita-cita tertinggi dari rakyat biasa. Hak-hak asasi manusia perlu dilindungi oleh peraturan hukum supaya orang tidak akan terpaksa memilih pemberontakan sebagai usaha terakhir guna menentang kelaliman dan penindasan. Dalam Pasal 1 disebutkan bahwa:

"Semua orang dilahirkan merdeka dan mempunyai martabat
dan hak-hak yang sama. Mereka dikaruniai akal dan hati
nurani dan hendaknya bergaul satu sama lain dalam semangat
persaudaraan".

Pasal 5 dinyatakan bahwa:

5 Ian Brownlie, ed.. "Basic Documents on Human Rights", (Oxford: Clarendon Press, 1971), 93-105. 
"Tidak seorang pun boleh disiksa atau diperlakukan secara kejam. memperoleh perlakuan atau dihukum secara tidak manusiawi atau direndahkan martabatnya".

Sebanyak 21 Pasal pertama Deklarasi tersebut menampilkan hak-hak yang sama dengan yang terdapat di dalam Pernyataan Hak Asasi Manusia (Bill of Rights) yang termaktub di dalam Konstitusi Amerika Serikat sebagaimana yang telah diperbarui saat ini. Hak-hak sipil dan politik ini meliputi hak atas perlindungan yang sama dan tidak pandang bulu, perlindungan hukum dalam proses peradilan, privasi dan integritas pribadi, serta partisipasi politik. Namun pasal 22 sampai 27 menciptakan kebiasaan baru. Pasal-pasal ini mengemukakan hak atas tunjangan ekonomi dan sosial seperti jaminan sosial -- suatu standar bagi kehidupan yang layak -- dan pendidikan. Hak-hak ini menegaskan bahwa, sesungguhnya, semua orang mempunyai hak atas pelayanan-pelayanan dari negara kesejahteraan.

Hak asasi manusia, sebagaimana yang dipahami di dalam dokumendokumen hak asasi manusia yang muncul pada abad ke-21 seperti Deklarasi Universal yang memiliki beberapa ciri-ciri yang menonjol. Pertama, supaya kita tidak kehilangan gagasan yang sudah tegas, hak asasi manusia adalah hak. Makna istilah ini tidak jelas -- dan akan menjadi salah satu obyek penelitian saya-- namun setidaknya kata tersebut menunjukkan bahwa itu adalah norma-norma yang pasti dan memiliki prioritas tinggi yang penegakannya bersifat wajib. ${ }^{6}$

Kedua, hak-hak ini dianggap bersifat universal, yang dimiliki oleh manusia semata-mata karena ia adalah manusia. Pandangan ini menunjukkan secara tidak langsung bahwa karakteristik seperti ras, jenis kelamin, agama, kedudukan sosial, dan kewarganegaraan tidak relevan untuk mempersoalkan apakah seseorang memiliki atau tidak memiliki hak asasi manusia. Ini juga menyiratkan bahwa hak-hak tersebut dapat diterapkan di seluruh dunia. Salah satu ciri khusus dari hak asasi manusia yang berlaku sekarang adalah bahwa itu merupakan hak internasional. Kepatuhan terhadap hak serupa itu telah dipandang sebagai obyek perhatian dan aksi internasional yang sah.

Ketiga, hak asasi manusia dianggap ada dengan sendirinya, dan tidak bergantung pada pengakuan dan penerapannya di dalam sistem adat atau sistem hukum di negara-negara tertentu. Hak ini boleh jadi memang belum merupakan hak yang efektif sampai ia dijalankan menurut hukum, namun hak itu eksis sebagai standar argumen dan kritik yang tidak bergantung pada penerapan hukumnya. 
Keempat, hak asasi manusia dipandang sebagai norma-norma yang penting. Meski tidak seluruhnya bersifat mutlak dan tanpa perkecualian, hak asasi manusia cukup kuat kedudukannya sebagai pertimbangan normatif untuk diberlakukan di dalam benturan dengan norma-norma nasional yang bertentangan, dan untuk membenarkan aksi internasional yang dilakukan demi hak asasi manusia. Hak-hak yang dijabarkan di dalam Deklarasi tersebut tidak disusun menurut prioritas; bobot relatifnya tidak disebut. Tidak dinyatakan bahwa beberapa di antaranya bersifat absolut. Dengan demikian hak asasi manusia yang dipaparkan oleh Deklarasi itu adalah sesuatu yang oleh para filsuf disebut sebagai prima facie rights.

Kelima, hak-hak ini mengimplikasikan kewajiban bagi individu maupun pemerintah. Adanya kewajiban ini, sebagaimana halnya hak-hak yang berkaitan dengannya, dianggap tidak bergantung pada penerimaan, pengakuan, atau penerapan terhadapnya. Pemerintah dan orang-orang yang berada di mana pun diwajibkan untuk tidak melanggar hak seseorang, kendati pemerintah dari orang tersebut mungkin sekaligus memiliki tanggung jawab utama untuk mengambil langkah-langkah positif guna melindungi dan menegakkan hak-hak orang itu.

Akhirnya, hak-hak ini menetapkan standar minimal bagi praktik kemasyarakatan dan kenegaraan yang layak. Tidak seluruh masalah yang lahir dari kekejaman atau tindakan mementingkan diri sendiri dan kebodohan merupakan permasalahan hak asasi manusia. Contohnya, suatu pemerintah yang gagal untuk menyediakan taman-taman nasional bagi rakyatnya memang dapat dikecam sebagai tidak cakap atau tidak cukup memperhatikan kesempatan untuk rekreasi, namun hal tersebut tidak akan pernah menjadi persoalan hak asasi manusia.

Meski hak asasi manusia dianggap menetapkan standar minimal, deklarasi-deklarasi kontemporer tentang hak asasi manusia cenderung untuk mencantumkan hak dalam jumlah yang banyak dan bersifat khusus, dan bukannya sedikit serta bersifat umum. Deklarasi Universal menggantikan tiga hak umum yang diajukan oleh Locke -- yakni hak atas kehidupan, kebebasan, dan kekayaan pribadi -- dengan sekitar Hak Asasi Manusia dua lusin hak khusus. Di antara hak-hak sipil dan politik yang dicanangkan adalah hak untuk bebas dari diskriminasi; untuk memiliki kehidupan, kebebasan, dan keamanan; untuk bebas beragama; untuk bebas berpikir dan

7 Untuk bahasan tentang soal apakah pemerintah- pemerintah yang bukan merupakan pemerintah yang membawahi seseorang juga harus menjaga hak asasi orang tersebut, lihat James W. Nickel, "Human Rights and the Rights of Aliens", di dalam Peter G. Brown dan Henry Shue, ed., "The Border That Joins", (Totowa, New York: Rowman \& Littlefield, 1983), 31-45. 
berekspresi; untuk bebas berkumpul dan berserikat; untuk bebas dari penganiayaan dan hukuman kejam; untuk menikmati kesamaan di hadapan hukum; untuk bebas dari penangkapan secara sewenang-wenang; untuk memperoleh peradilan yang adil; untuk mendapat perlindungan terhadap kehidupan pribadi (privasi); dan untuk bebas bergerak. Hak sosial dan ekonomi di dalam Deklarasi mencakup hak untuk menikah dan membentuk keluarga, untuk bebas dari perkawinan paksa, untuk memperoleh pendidikan, untuk mendapatkan pekerjaan, untuk menikmati standar kehidupan yang layak, untuk istirahat dan bersenang-senang, serta untuk memperoleh jaminan selama sakit, cacat, atau tua.

Deklarasi Universal menyatakan bahwa hak-hak ini berakar di dalam martabat dan harkat manusia, serta di dalam syarat-syarat perdamaian dan keamanan domestik maupun internasional. Dalam penyebarluasan Deklarasi Universal sebagai sebuah "standar pencapaian yang bersifat umum," PBB tidak bermaksud untuk menjabarkan hak-hak yang telah diakui di manamana atau untuk mengundangkan hak-hak ini di dalam hukum intemasional. Justru Deklarasi tersebut mencoba untuk mengajukan norma-norma yang ada di dalam moralitas-moralitas yang sudah mengalami pencerahan. Meski tujuan sejumlah besar partisipan Deklarasi itu adalah untuk menampilkan hak-hak ini di dalam sistem hukum domestik maupun internasional, hak tersebut dipandang bukan sebagai hak-hak hukum (legal rights) melainkan sebagai hak-hak moral yang berlaku secara universal (universal moral rights).

Turunan-turunan Deklarasi Universal tidak hanya meliputi pernyataan hak asasi manusia di dalam banyak konstitusi nasional melainkan juga sejumlah perjanjian internasional tentang hak asasi. Pertama dan bisa dibilang yang paling berarti adalah Konvensi Eropa tentang Hak Asasi Manusia (European Convention on Human Rights). Konvensi yang dicetuskan di Dewan Eropa (European Council) pada 1950 ini menjadi sistem yang paling berhasil yang dibentuk demi penegakan hak asasi manusia. ${ }^{8}$ Konvensi ini menyebutkan hak-hak yang kurang lebih serupa dengan yang terdapat di dalam dua puluh satu pasal pertama Deklarasi Universal. Konvensi tersebut tidak memuat hak ekonomi dan hak sosial; hakhak ini dialihkan ke dalam Perjanjian Sosial Eropa (European Social

${ }^{8}$ Ihwal sistem Eropa, lihat Frede Castberg, "The European Convention on Human Rights", (Dobbs Ferry, New York: Oceana Publications, 1974): James E.S. Fawcett, "The Application of the European Convention on Human Rights". (Oxford: Clarendon Press, 1969): dan Secretary to the European Commission of Human Rights, "Stock-Taking on the European Convention on Human Rights: A Periodic Note on the Concrete Results Achieved Under the Convention". (Strasbourg: Dewan Eropa, 1979). 
Covenant), dokumen yang mengikat para penandatangannya untuk mengangkat soal penyediaan berbagai tunjangan ekonomi dan sosial sebagai tujuan penting pemerintah.

Sejumlah kalangan mengusulkan agar suatu pernyataan mengenai hak asasi manusia internasional di PBB hendaknya tidak berhenti hanya menjadi suatu deklarasi melainkan juga tampil sebagai norma-norma yang didukung oleh prosedur penegakan yang mampu mengerahkan tekanan intemasional terhadap negara-negara yang melanggar hak asasi manusia secara besarbesaran. Rencana yang muncul di PBB adalah meneruskan Deklarasi Universal dengan perjanjian-perjanjian yang senada. Naskah Perjanjian Internasional (International Covenants) diajukan ke Majelis Umum guna mendapatkan persetujuan pada tahun 1953. Untuk menampung usulan mereka yang meyakini bahwa hak ekonomi dan hak sosial bukan merupakan hak asasi manusia yang sejati atau bahwa hak-hak tersebut tidak dapat diterapkan dalam cara yang sama dengan penerapan hak-hak sipil dan politik, dua perjanjian dirancang, yaitu Perjanjian Hak-hak Sipil dan Politik (Covenant on Civil and Political Rights) serta Perjanjian Hak-hak Ekonomi, Sosial, dan Budaya (Covenant on Economic, Social, and Cultural Rights).

Lantaran permusuhan dalam era Perang Dingin saat itu, dan tamatnya dukungan bagi perjanjian hak asasi manusia yang dibuat Amerika Serikat, gerakan yang didasarkan pada Perjanjian Internasional ditangguhkan dalam waktu yang lama. Perjanjian itu belum juga disetujui Majelis Umum sampai 1966. Selama tahun-tahun tersebut ketika Perjanjian itu tampaknya tak berpengharapan, PBB mengeluarkan sejumlah perjanjian hak asasi manusia yang lebih terbatas yang bersangkutan dengan topik-topik yang relatif tidak kontroversial seperti pemusnahan suku bangsa / genosid, perbudakan, pengungsi, orang-orang tanpa kewarganegaraan, serta diskirminasi. Perjanjian-perjanjian ini umumnya ditandatangani oleh sejumlah besar negara -- walau tidak ditandatangani oleh Amerika Serikat -- dan lewat mereka PBB mulai memetik sejumlah pengalaman untuk menjalankan perjanjian-perjanjian hak asasi manusia.

Pada selang waktu antara Deklarasi Universal yang terbit pada tahun 1948 dan persetujuan akhir Majelis Umum bagi Perjanjian Intemasional yang keluar pada tahun 1966, banyak negara Afrika dan Asia yang baru saja terbebas dari kekuasaan penjajahan dari negara lain, memutuskan untuk masuk ke dalam PBB. Negara-negara ini umumnya bersedia mengikuti upaya berani untuk menegakkan hak asasi manusia, namun mereka memodifikasikannya guna mewakili kepentingan dan kebutuhan mereka sendiri. Kepentingan dan kebutuhan mereka sendiri antara lain adalah mengakhiri kolonialisme, mengutuk eksploitasi negara-negara Barat terhadap 
negara-negara sedang berkembang, serta menghancurkan apartheid dan diskriminasi rasial di Afrika Selatan.

Setelah persetujuan dari Majelis Umum keluar pada tahun 1966, Perjanjian itu memerlukan tanda tangan dari tiga puluh lima negara untuk diikat di dalam daftar para penandatangan. Negara ketiga puluh lima menerakan tandatangan pada tahun 1976, dan Perjanjian itu kini berlaku sebagai hukum internasional.

\section{Laporan Tahunan Tentang Praktek Hak Asasi Manusia Di Indonesia}

Pada tahun 2005 Biro Demokrasi, Hak Asasi Manusia, dan Buruh mengeluarkan Laporan Tahunan Tentang Praktek Hak Asasi Manusia di Indonesia. Hak asasi manusia di Indonesia dipengaruhi oleh berbagai aspek, termasuk di dalamnya aspek politik, sosial dan ekonomi.

Dipantau dari aspek politik, Indonesia adalah suatu negara republik dengan sistem presidential dan tiga cabang pemerintahan. Presiden adalah kepala negara dan menjabat selama masa jabatan lima-tahun untuk maksimum dua kali masa jabatan. Pada tanggal 20 Oktober, Susilo Bambang Yudhoyono, presiden pertama di Indonesia yang terpilih secara langsung oleh warga negara, Harapan yang timbul dengan adanya perubahan sistem politik adalah salah satunya peningkatan terhadap perlindungan hak asasi manusia. Namun dalam faktanya, sejak terpilihanya Susilo Bambang Yudhoyono sampai dengan saat ini, pelanggaran hak asasi manusia di Indonesia masih saja terjadi. Bahkan yang lebih parah. banyak sekali pelanggaran hak asasi manusia terjadi pada masyarakat dalam hak untuk memperoleh kehidupan yang layak. Sebagai contoh, korban penggusuran semakin banyak. Bahkan penggusuran tidak langsung terjadi pada masyarakat di Sidoarjo akibat lumpur Lapindo yang sampai dengan saat ini tidak jelas penyelesaiannya. Presiden mengeluarkan Peraturan Presiden yang isinya mengatur permasalahan jangka waktu penyelesaian permasalahan lumpur Sidoarjo tersebut oleh pihak-pihak yang harusnya bertanggungjawab. Sekali lagi, dalam faktanya, sampai dengan habisnya deadline tersebut masih saja permasalahan tidak kunjung teratasi.

Tentara Nasional Indonesia (TNI) secara resmi mempunyai tanggung jawab terhadap pertahanan eksternal, dan Polisi Republik Indonesia untuk keamanan internal; namun di dalam praktek, pembagian tanggung jawab tetap tidak jelas. Bersama-sama keduanya dikenal sebagai satuan keamanan. Militer memainkan suatu peranan dalam masalah keamanan internal, khususnya di daerah-daerah konflik seperti Aceh, Maluku, Sulawesi Tengah, 
dan Papua (sebelumnya dikenal sebagai Irian Jaya). Terdapat friksi yang besar antara polisi dan TNI, tetapi operasi bersama adalah-umum di daerahdaerah konflik. Di daerah-daerah konflik ini juga masih sangat rentan terjadi pelanggaran hak asasi manusia baik yang dilakukan oleh oknum-oknum yang tidak bertanggungjawab maupun oleh pihak aparat negara sendiri (TNIPOLRI).

Selama tahun 2007 ini, ekonomi, yang semakin dikendalikan pasar, diperkirakan tumbuh sekitar 4,8 persen. Namun, hal ini ternyata tidak berhasil mengurangi angka pengangguran atau menyerap sekitar 2,5 juta pencari kerja baru yang memasuki pasar setiap tahun. Jumlah penduduk Indonesia saat ini kira-kira 238 juta jiwa. Angka kemiskinan munurut statistik yang dikeluarkan oleh BPS memang mengalami penurunan, namun realitanya kesemrawutan yang diakibatkan oleh kemiskinan masih menjadi pemandangan sehari-hari masyarakat kita. Perkiraan penghasilan per kapita adalah US\$ 867. Permintaan konsumen merupakan kekuatan utama dalam mengendalikan pertumbuhan ekonomi.

Catatan terhadap kinerja pemerintah di bidang hak asasi manusia masih terbilang buruk; walaupun tidak bisa kita sanggah bahwa telah ada perbaikan di beberapa bidang. Aparatur negara masih sering melakukan pelanggaran hak asasi manusia, banyak tindakan kekejaman yang dilakukan di daerah-daerah konflik separatis. Anggota satuan keamanan membunuh, menganiaya, memperkosa, memukul, dan secara sewenang-wenang menahan warga sipil serta para anggota gerakan separatis, khususnya di Aceh dan pada tingkat yang lebih kecil di Papua. Beberapa petugas polisi kadang-kadang menggunakan kekuatan yang berlebihan dan kadangkala mematikan dalam menahan tersangka dan dalam usaha untuk memperoleh informasi atau pengakuan. Tindakan ini tentu saja bertentangan dengan sistem hukum acara pidana Indonesia yang secara terang menganut sistem due process mode atau akusatur dan bukanlah sistem crime control model atau inkuisituur yang masih gemar dilakukan oleh aparatur negara. Hal ini dipandang lebih efektif bagi para aparatur negara kita tanpa memandang sisi perlindungan hak asasi manusia dan kemanusiaan.

Ironisnya, para perwira militer purnawirawan dan yang masih bertugas aktif, diketahui telah melakukan pelanggaran hak asasi manusia berat, justru menduduki atau mendapat promosi pada jabatan-jabatan senior di lembaga pemerintahan dan TNI. Kondisi penjara tetap kejam dan para narapidana masih sering diperlakukan di luar rasa kemanusiaan yang wajar. Sistem peradilannya masih membudayakan budaya korupsi, yang menambah kegagalan untuk memberikan ganti rugi kepada para korban pelanggaran hak asasi manusia atau meminta pertanggungjawaban para pelaku. Para pelanggar hak asasi masusia dari satuan keamanan kadang-kadang 
menggunakan intimidasi dan penyuapan untuk menghindari keadilan. Selain itu perselisihan tanah masih menimbulkan banyak pelanggaran hak asasi manusia. Kaum yang the have not masih menjadi kaum yang tertindas. Hal tersebut seringkali melibatkan pengusiran paksa, beberapa diselesaikan dengan kekuatan yang mematikan.

Para politikus dan pembesar memperlihatkan keinginan yang lebih besar untuk mengambil tindakan hukum terhadap organisasi-organisasi berita yang menurut mereka pemberitaannya menghina atau menyerang, dan kecenderungan ini mempunyai suatu akibat yang menakutkan bagi beberapa pemberitaan investigatif. Para anggota satuan keamanan dan kelompokkelompok lain kadang-kadang membatasi kebebasan berekspresi dengan mengintimidasi atau menyerang wartawan yang tulisannya menurut mereka tidak dapat diterima. Pemerintah membatasi pers asing untuk melakukan perjalanan ke daerah-daerah konflik di Aceh, Papua, Sulawesi dan Maluku. Pemerintah seringkali membatasi kegiatan organisasi non-pemerintah (LSM), khususnya di Aceh dan Papua.

\section{Penutup}

Selain pelanggaran hak asasi manusia yang dapat menimpa semua orang dalam setiap lapisan masyarakat. Pelanggaran-pelanggaran hak asasi manusia terhadap perempuan dan anak-anak tidak saja terjadi di ruang publik tetapi juga di ruang domestik. Perempuan dan anak-anak dalam banyak kesempatan seringkali menjadi korban kekerasan secara berganda. Artinya tidak hanya menjadi korban fisik, tetapi juga psikis, sosial dan budaya dalam masyaraka.

Berkaitan dengan sejumlah kasus-kasus yang terjadi terhadap perempuan dan anak, perlu kiranya dibuat ketentuan hukum yang lebih spesifik dan tegas untuk menegakkan hak asasi perempuan dan anak-anak. Ketetapan hukum ini tidak bisa dibuat secara umum, karena permasalahanpermasalahan perempuan dan anak-anak biasanya terjadi dengan spesifikasi tertentu, sehingga tidak bisa digeneralisasi. Untuk itu, perlu adanya paradigma baru dalam konteks penanganan perempuan dan anak korban pelanggaran hak asasi di Indonesia secara lebih inklusif dan comprehensive. Dengan demikian diharapkan masalah-masalah hak asasi manusia yang menimpa perempuan dan anak secara khusus dan masyarakat luas secara umum dapat terakomodasi dengan baik. 


\section{Daftar Pustaka}

Brownlie, Ian, ed. Basic Documents on Human Rights Oxford: Clarendon Press, 1971.

Castberg, Frede. The European Convention on Human Rights, Dobbs Ferry, New York: Oceana Publications, 1974;

European Commission of Human Rights, Stock-Taking on the European Convention on Human Rights: A Periodic Note on the Concrete Results Achieved Under the Convention, Strasbourg: Dewan Eropa, 1979.

Fawcett, James E.S. The Application of the European Convention on Human Rights, Oxford: Clarendon Press, 1969.

Humphrey, John P. Human Rights and the United Nations: A Great Adventure, Dobbs Ferry, New York Transnational Publishers, 1984.

Indonesia. Undang-Undang No. 39 Tahun 1999 Tentang Hak Asasi Manusia.

Lurton, Douglas. Roosevelt's Foreign Policy, 1933 1941: Franklin D. Roosevelt's Unedited Speeches, Toronto: Longmans, Green, 1942.

Muladi. Demokratisasi, Hak Asasi Manusia, dan Reformasi Hukum di Indonesia, Jakarta: The Habibie Center, 2002.

Nasution, Adnan Buyung dan A. Patra M. Zen. Instrumen Internasional Pokok Hak Asasi Manusia, Jakarta: Yayasan Obor Indonesia, 2006.

Panhuys, H.F. van, dkk., ed. International Organization and Integration, The Hague: Martinus Nijhoff, 1981, vol. 1A.

Sohn, Louis B. A Short History of the United Nations Documents on Human Rights, di dalam Commission to Study the Organization of Peace, The United Nations and Human Rights: Eighteenth Report of the Commission, Dobbs Fery, New York: Transnational Publishers, 1968.

YLBHI. Laporan Tahun 2004 Yayasan Lembaga Bantuan Hukum Indonesia. Jakarta: Sentralisme Production, 2004. 